\title{
Large Dentigerous Cyst of the Mandible that Surgically Enucleated Following 9-Months Marsupialization in a Young Female Patient: A Case Report
}

\author{
Genç Kadın Hastada Mandibulada Yer Alan Büyük Dentigeröz Kistin 9 Aylık Marsupyalizasyon Sonrası Cerrahi \\ Enüklasyonu: Olgu Sunumu
}

Kadriye Ayça Dere ${ }^{1}$, Sara Samur-Ergüven², Emre Barış

${ }^{1}$ Pamukkale University Faculty of Dentistry, Department of Oral and Maxillofacial Surgery, Denizli, Turkey

${ }^{2} 75$.YIl Oral and Dental Health Hospital, Oral Surgery Clinic, Ankara, Turkey

${ }^{3}$ Gazi University, Faculty of Dentistry, Department of Oral Pathology, Ankara, Turkey

\section{ABSTRACT}

Dentigerous cyst is the most common type of developmental odontogenic cyst and it is commonly associated with the crown of an impacted tooth. Owing their asymptomatic behavior it is likely to cause significant bone resorption/ expansion and tooth displacement. This case report presents a large developmental dentigerous cyst located at the ramus mandible of a 30 -yearold female patient that was managed conservatively by surgical approach after 9-month marsupialization treatment.

Key Words: Dentigerous cyst, mandible, marsupialization

Received: 09.23 .2018

Accepted: 12.17 .2018
ÖZET

Dentigeröz kistler gelişimsel odontojenik kistlerin en sık görüleni olup çoğunlukla gömülü bir diş kronu ile ilişki halindedirler. Asemptomatik yapıları nedeniyle ciddi kemik kaybı/ekspansiyonuna ve dişlerde yer değiştirmelere neden olabilirler. Bu olgu bildiriminde 30 yaşında bir kadın hastada mandibula ramus bölgesinde yer alan büyük gelişimsel dentigeröz kistin 9 aylık marsupyalizasyon tedavisi sonrası konservatif cerrahi yaklaşımla gerçekleştirilen tedavisi sunulmaktadır.

Anahtar Sözcükler: Dentigeröz kist, mandibula, marsupyalizasyon

Geliş Tarihi: 23.09 .2018

Kabul Tarihi: 17.12 .2018

\section{INTRODUCTION}

Dentigerous cysts are the most common type of developmental odontogenic cyst that usually occur in the second and third decades of life (1). The exact pathogenesis of dentigerous cyst is still unclear; however developmental origin from tooth follicles thought to be responsible (2). They are usually asymptomatic and associated with the crown of an unerupted or impacted tooth. Owing to asymptomatic behavior, it is likely to cause significant bone resorption and cortical expansion (3).

Treatment modalities of a dentigerous cyst include enucleation or marsupialization. Marsupialization is a conservative approach that decreases the size of the cyst gradually. The procedure involves making a window on the cystic wall by incision, evacuation of the contents of the cyst and suturing the cystic lining to the oral mucosa (3). Marsupialization is effective in reducing both the size of cystic lesions on the jaws and associated morbidity of resection.

\section{CASE REPORT}

A 30-year-old female patient referred to our clinic with a complaint of a pain at the right maxillary third molar tooth. On extraoral examination, a slight buccal asymmetry was detected. Intraoral examination revealed a decay at the right maxillary third molar tooth, but besides that, a painless swelling was identified that might be related with facial asymmetry at the right mandibular ramus region. A panoramic examination requested to evaluate the radiologic condition, and it revealed a well-defined unilocular radiolucency at the mandibular posterior ramus region that includes impacted right mandibular third molar. The lesion extended from the distal surface of the second molar to the ramus mandible (Figure 1 ). 


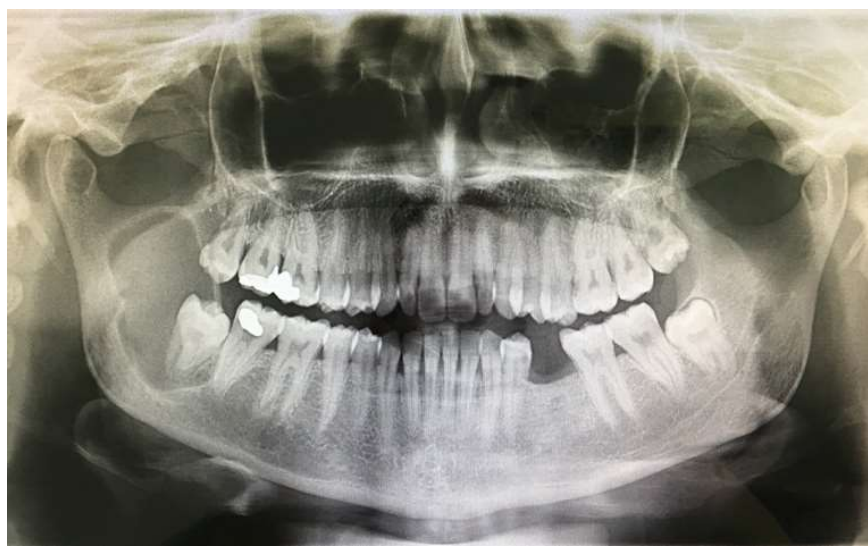

Figure 1. Panoramic image of the lesion.

A provisional diagnosis of the dentigerous cyst was made. Marsupialization of the cyst simultaneously with incisional biopsy was planned under local anesthesia to prevent potential damage of radical surgery to the adjacent anatomic tissues. The patient was informed about treatment procedure and informed consent obtained.

On the day of surgery, the patient rinsed with $2 \%$ chlorohexidine mouthwash. Local anesthesia was achieved by inferior alveolar nerve block that supported by infiltration anesthesia on the buccal mucosa (Maxicaine fort ${ }^{\circledR} 2 \mathrm{ml}$, Vem Illaç, Ankara, Turkey). A mucoperiosteal flap was reflected by sulcular and releasing incisions. The cystic lining was excised at the roof of the lesion meticulously. Impacted mandibular third molar extracted easily owing to adjacent bone loss. The cystic fluid was evacuated and region irrigated with saline. The margin of the cystic lining was sutured to the adjacent margin of the wound. Plastic drain obtained from pacifier was inserted into the cavity for keeping the path clear. The sulcular and releasing incision was sutured by 3-0 resorbable suture material (Pegelak 3/0, Doğsan, Trabzon, Turkey). The patient was prescribed with antibiotic and analgesic. The excised lining of the lesion was sent for histopathologic examination. The patient was strongly advised to protect the jaw region for traumatic events and use another side of the jaw while chewing. Oral hygiene instructions were given. Histopathological evaluation revealed that the lesion was dentigerous cyst that has been secondarily infected (Figure 2). Cystic lesion lined with several layers of nonkeratinized odontogenic epithelium. Connective tissue is edematous and contains intense lymphocytic inflammation. Follow-up was carried out after one week then monthly intervals in 9 month period. Panoramic image at the $9^{\text {th }}$ month shown that lesion shrank noticeably (Figure 3 ).

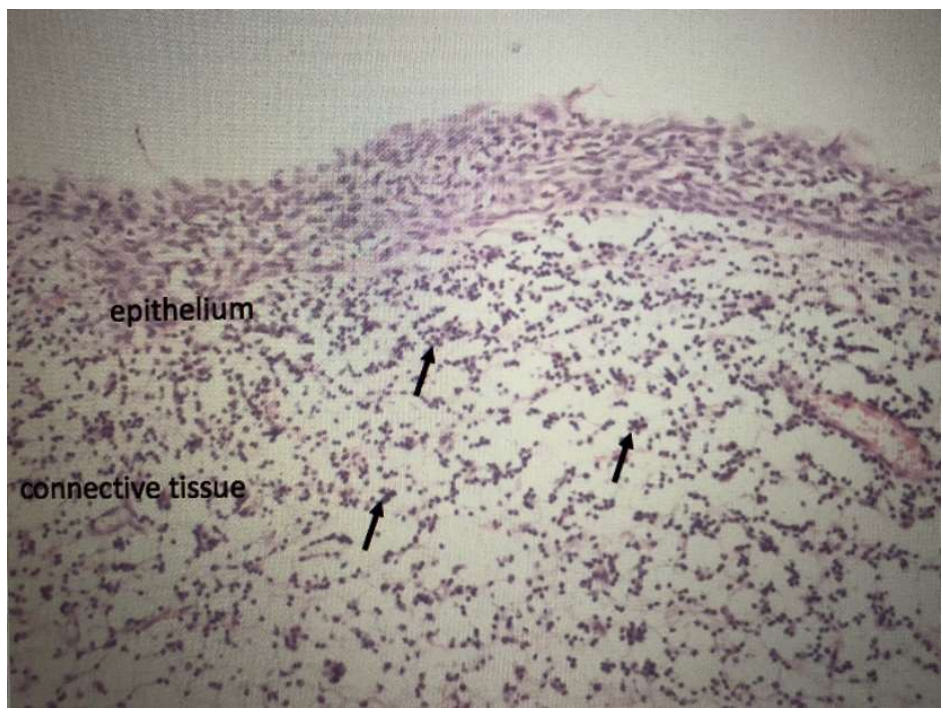

Figure 2. Cystic lesion lined with several layers of non-keratinized odontogenic epithelium. Connective tissue is edematous and contains intense lymphocytic inflammation (arrow). (Hematoxylin\&Eosin x200)

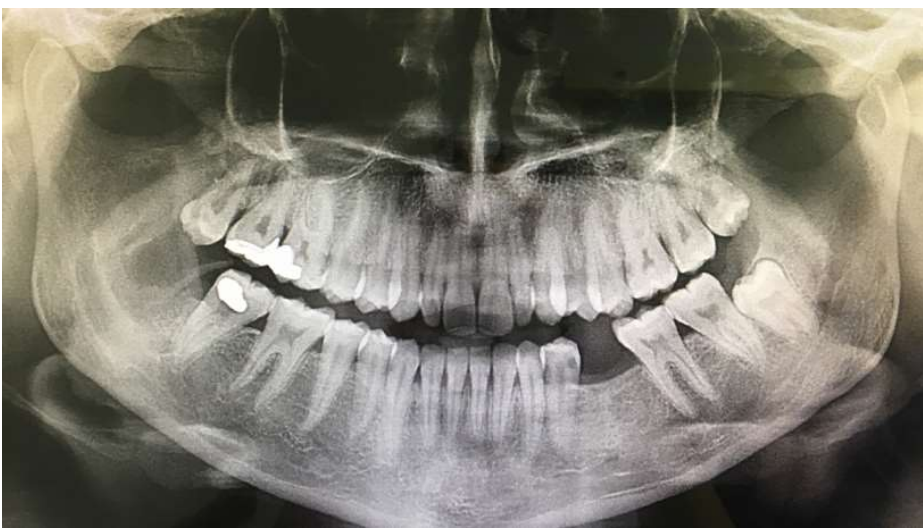

Figure 3. Panoramic image of the lesion at the $9^{\text {th }}$ month follow-up.

No complications had been noted in the follow-up period of nine months. A second surgery was performed to eradicate remaining cystic tissues under local anesthesia following marsupialization treatment. Excisional biopsy revealed that final diagnoses as a dentigerous cyst that has been secondarily infected (Figure 4). Histologically cystic lesion lined with thin non-keratinized odontogenic epithelium. Squamous metaplasia was seen in many parts of cyst epithelium. Moreover, dense chronic inflammatory cellular infiltration was observed in fibrous wall of the cyst. All these findings were diagnosed as a dentigerous cyst. No recurrences had been noted on follow-up period of three months following surgery.

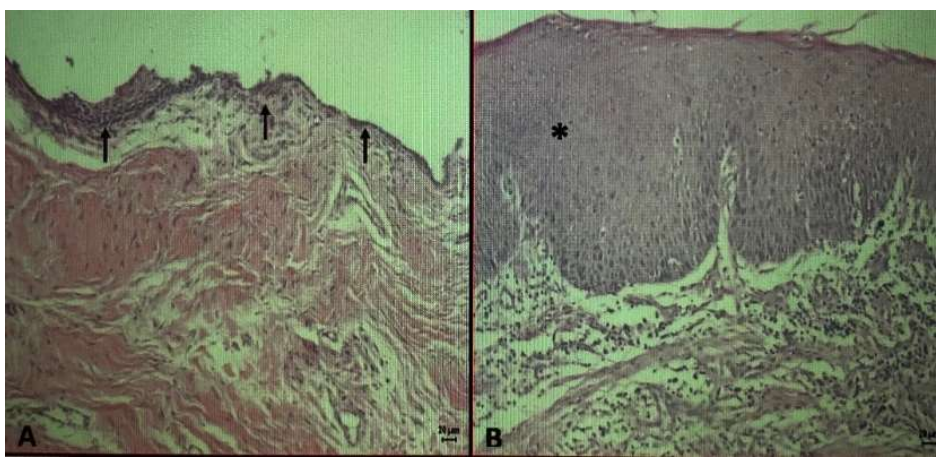

Figure 4. A: The cystic lesion lined with non-keratinized simple odontogenic epithelium (arrow).

$B:$ Squamous metaplasia $\left({ }^{*}\right)$ and inflammatory cell infiltration were seen in many areas of the cyst (A,B: Hematoxylin\&Eosin $x 200)$

\section{DISCUSSION}

Marsupialization is an important treatment modality for odontogenic cystic lesions of the jaw (4). This conservative approach ensures us to refrain from radical treatment options such as resections or gross surgical enucleations. That treatment manner would be beneficial for especially in young patients as in this case report. The necessity for a second operation and longer duration of follow-up periods can be disadvantages of this technique.

In the present case, the lesion was managed conservatively by surgical approach following 9-months marsupialization treatment with the functionally favorable outcome.

A literature review reported that marsupialization could be performed as a single surgical procedure or combined with other treatment approaches for many cystic lesions in different sites of the jaws. The long-term observation confirmed the effectiveness of the treatment (5). It has been accepted and used as a conservative surgical option for both children and adults $(4,6)$ Based on another review article's findings, it is recommended to consider primary decompression or marsupialization followed by surgery for the treatment of large jaw cysts to achieve sufficient clinical results (7).

Song et al. reported that despite the need for a second operation and longer duration of treatment compared with surgery alone, decompression is a valuable way of reducing the size of large cystic lesions, with low morbidity and recurrence rate (8). Dentigerous cysts are a common pathology of the oral region that can be treated effectively with different treatment modalities that can be applied solely or in combination. Despite their benign origin and behavior, cysts in the oral cavity require appropriate clinical management. 
Dere et al.

A study that include retrospective clinicopathological analysis of dentigerous cysts showed that lesions appear clinically as dentigerous cyst can includes histologically as more severe conditions as odontogenic keratocyst or ameloblastoma (9). For differential diagnosis of the oral lesions, histopathological examination plays a crucial role.

\section{CONCLUSION}

Marsupialization was effective in reducing the size of the cystic lesion of the mandible for this case. That conservative approach ensures us to refrain from radical surgical options.

\section{Conflict of interest}

No conflict of interest was declared by the authors.

\section{REFERENCES}

1. Martínez-Pérez D, Varela-Morales M. Conservative treatment of dentigerous cysts in children: a report of 4 cases. J Oral Maxillofac Surg 2001; 59:331-3.

2. Ghandour L, Bahmad HF, Bou-Assi S. Conservative treatment of dentigerous cyst by marsupialization in a young female patient: A case report and review of the literature. Case Rep Dent. 2018; 7621363.
3. Abu-Mostafa N, Abbasi A. Marsupialization of a large dentigerous cyst in the mandible with orthodontic extrusion of three impacted teeth. A case report. J Clin Exp Dent. 2017; 9:e1162-e1166.

4. Gao L, Wang XL, Li SM, Liu CY, Chen C, Li JW, et al. Decompression as a treatment for odontogenic cystic lesions of the jaw. J Oral Maxillofac Surg. 2014; 72:327-33.

5. Hou R, Zhou H. Articles of marsupialization and decompression on cystic lesions of the jaws: A literature review. Journal of Oral and Maxillofacial Surgery, Medicine and Pathology. 2013; 299-304.

6. Singh S, Kaur K, Kochhar GK, Gupta A. Marsupialisation: a treatment modality of a dentigerous cyst. BMJ Case Rep. 2014; 2014-205150.

7. Wakolbinger R, Beck-Mannagetta J. Long-term results after treatment of extensive odontogenic cysts of the jaws: a review. Clin Oral Investig. 2016; 20: $15-22$.

8. Song IS, Park HS, Seo BM, Lee JH, Kim MJ. Effect of decompression on cystic lesions of the mandible: 3-dimensional volumetric analysis. $\mathrm{Br} J$ Oral Maxillofac Surg. 2015; 53: 841-8.

9. Zhang LL, Yang R, Zhang L, Li W, MacDonald-Jankowski D, Poh CF. Dentigerous cyst: a retrospective clinicopathological analysis of 2082 dentigerous cysts in British Columbia, Canada. Int J Oral Maxillofac Surg. 2010; 39: 878-82. 